\title{
"Switzerland must be a special democracy": Sociopolitical Compromise, Military Comradeship, and the Gender Order in 1930s and 1940s Switzerland*
}

\author{
Christof Dejung \\ Universität Konstanz.
}

The twentieth century's two world wars not only produced hitherto unimagined destruction; in many countries they also gave new impetus to calls for emancipation in the gender order. The experiences many women had while working in "male" occupations during the war could not simply be ignored after the fighting ended. ${ }^{1}$ The suspension of the traditional gender system provoked massive ideological opposition that attempted to define the social, economic, and military benefits of women's participation in the war effort as the temporary product of an exceptional situation and, at the same time, to reinstate the traditional gender order. Yet it is interesting to note that it was precisely in the periods that followed the world wars that women gained the right to vote in many modern nations. ${ }^{2}$ Remarkably, it was Switzerland, of all places-a country that in the nineteenth century was among the avant-garde in republican-democratic political thought - that did not grant women the right to vote until 1971, at which point the country was almost dead last in Europe in terms of progressive gender politics. ${ }^{3}$ That the Swiss did not establish women's suffrage after either of the world wars shows that the right to vote was not an automatic reward for women's efforts in the wars: other processes, both political and sociocultural, were also in play.

Many authors have described the Swiss political system-in which a high degree of local autonomy and democratic rights gives citizens the right to vote in referendums on constitutional reforms and on other changes to the law-as having been the greatest obstacle to equal rights for Swiss women. In addition, the argument runs, small-scale structures enabled men to come to political

* This essay was translated for the Journal of Modern History by Nick Hoff.

${ }^{1}$ Thomas Kühne, "Der Soldat," in Der Mensch des 20. Jahrhunderts, ed. Ute Frevert and Heinz-Gerhard Haupt (Frankfurt am Main and New York, 1999), 365.

${ }^{2}$ This was the case in, for example, Great Britain, Germany, and the United States after World War I and for France and Italy after World War II. See Joan Scott, "Rewriting History," in Behind the Lines: Gender and the Two World Wars, ed. Margaret R. Higonnet and Jane Jenson (New Haven, CT, 1987), 24.

${ }^{3}$ Political rights in Switzerland consist of a right to vote on specific issues, active and passive voting rights, and the right to launch and sign initiatives and referendums. 
agreements behind the scenes. ${ }^{4}$ But this view does not explain why male Swiss citizens were suddenly ready, in 1971, to grant women political rights. Furthermore, the political scientist Sibylle Hardmeier has shown that Switzerland's system of direct democracy can be held only partly responsible for the late arrival of political equality for Swiss women. For before the 1960s, not only male voters in general but most representatives in the national parliament were not especially interested in women's political equality. ${ }^{5}$

It is clear, then, that other factors must underlie Switzerland's remarkable backwardness in introducing political equality for women at such a late date. The numerous studies of Swiss women's fight for political rights, however, offer relatively few approaches to this issue. As a rule, they are limited to analyzing the strategies of women's rights activists and the political debates surrounding the votes to introduce women's suffrage. ${ }^{6}$ Not only has no connection been made between the question of women's suffrage and sociopolitical and party-political processes, but we also lack a detailed international comparison that could clarify why exactly Swiss women had to wait so long for active political rights. It is true that some military histories suggest that Switzerland's being spared invasion and combat during the two world wars led to a stabilization in gender relations. However, this idea has neither been investigated in detail nor placed in a larger sociohistorical context. ${ }^{7}$ In this essay, I examine these issues and, I hope, make the analysis of social and gender politics in Switzerland in the 1930s and 1940s relevant to the recent

${ }^{4}$ See Joy Charnley, Malcolm Pender, and Andrew Wilkins, eds., Twenty-five Years of Emancipation? Women in Switzerland, 1971-1996 (Bern, 1998).

${ }^{5}$ Sibylle Hardmeier, Frühe Frauenstimmrechtsbewegung in der Schweiz (1890-1930): Argumente, Strategien, Netzwerk, und Gegenbewegung (Zurich, 1997), 202-44.

${ }^{6}$ Brigitte Studer, "'L'État c'est l'homme': Politique, citoyenneté et genre dans le débat autour du suffrage féminin après 1945," Schweizerische Zeitschrift für Geschichte 46 (1996): 356-82; Yvonne Voegeli, Zwischen Hausrat und Rathaus: Auseinandersetzungen um die politische Gleichbehandlung der Frauen in der Schweiz. 1945-1971 (Zurich, 1997); Hardmeier, Frühe Frauenstimmrechtsbewegung in der Schweiz; Beatrix Mesmer, Staatsbürgerinnen ohne Stimmrecht: Die Politik der schweizerischen Frauenverbände 1914-1971 (Zurich, 2007). An exception, however, is Regula Ludi, "Gendered Citizenship in Switzerland: The Significance of the Memory of World War II for the Political Exclusion of Women after 1945," in Nation and Gender in Contemporary Europe: Exploring the East-West Divide, ed. Stephenie Booth and Vera Tolz (Manchester, 2005), 53-79.

7 Thus, see, e.g., Jakob Tanner, "'Reduit national' und Aussenwirtschaft," in Raubgold, Reduit, Flüchtlinge: Zur Geschichte der Schweiz im Zweiten Weltkrieg, ed. Philipp Sarasin and Regina Wecker (Zurich, 1998), 100; Annette Frei Berthoud, "Fakten, Mythen, Erinnerungen: Die unterschiedliche Wahrnehmung und Beurteilung von Aktivdienst und Fraueneinsatz," in ibid., 107; Regina Wecker, "Es war nicht Krieg! Die Situation der Schweiz 1939-1945 und die Kategorie Geschlecht," in Armee, Staat, und Geschlecht: Die Schweiz im internationalen Vergleich 1918-1945, ed. Christof Dejung and Regula Stämpfli (Zurich, 2003), 43. 
broader debate on the relationship between the experience of war and the gender order. ${ }^{8}$ At the same time, I will analyze gender politics during and immediately following wartime and their connection to the class politics of the day. With this approach, I hope to shed light on a complex of themes that remains quite underdeveloped in most studies. ${ }^{9}$

An important reason for Switzerland's late introduction of women's suffrage lies in the fact that the country was one of the few European nations that was largely spared the consequences of war between 1939 and $1945 .{ }^{10}$ In contrast to the warring countries, where the brutality of modern warfare had devalued the model of the soldierly man, Switzerland carried over its gender models more or less unchanged into the postwar period. ${ }^{11}$ Because images of men and women within the gender order are interdependent, the hegemony of an ideological construct such as that of military masculinity can constitute a discursive basis for justifying the political domination of men as a group over women. ${ }^{12}$ The view that the army, and thus the men who had to perform military service, had saved Switzerland from a German assault - a view that prevailed almost unchallenged for decades in the postwar period-also affected women's political situation, not least because civil rights were traditionally understood as a quid pro quo for the fulfillment of the duty of military service. That a considerable portion of young men (up to 40 percent of those called up in the 1920s) were declared unfit for service as a result of their army physicals played no role in this pattern of interpretation. It is true that men who were deemed unfit for service and hence did not serve in the military were regarded as less masculine than the "real" men" who had completed their

${ }^{8}$ Compare, among others, Joanna Bourke, Dismembering the Male: Men's Bodies, Britain, and the Great War (London, 1996); and Karen Hagemann and Stefanie Schüler-Springorum, eds., Home/Front: The Military, War, and Gender in TwentiethCentury Germany (Oxford, 2002).

${ }^{9}$ Connecting the analyses of gender politics and party politics will fill a shortcoming in the research that Thomas Kühne bemoaned several years ago. See Thomas Kühne, "Staatspolitik, Frauenpolitik, Männerpolitik: Politikgeschichte als Geschlechtergeschichte," in Geschlechtergeschichte und Allgemeine Geschichte: Herausforderungen und Perspektiven, ed. Hans Medick and Anne-Charlotte Trepp (Göttingen, 1998), 226.

${ }^{10}$ The other European countries not involved directly in the war were Sweden, Ireland, Portugal, Turkey, and Spain. See Eric Hobsbawm, Age of Extremes: The Short Twentieth Century, 1914-1991 (London, 1995), 24.

${ }^{11}$ On the changes in the gender order in warring states after both world wars, see Claire Duchen and Irene Bandhauer-Schöffmann, "Introduction," in When the War Was Over: Women, War, and Peace in Europe, 1940-1956, ed. Claire Duchen and Irene Bandhauer-Schöffmann (London and New York, 2000), 3; Margaret R. Higonnet and Patrice L.-R. Higonnet, "The Double Helix," in Higonnet and Higonnet, Behind the Lines, 33-51.

${ }^{12}$ Lynn Hunt, "The Challenge of Gender: Deconstruction of Categories and Reconstruction of Narratives in Gender History," in Medick and Trepp, Geschlechtergeschichte und Allgemeine Geschichte, 78-79. 
military service, but the status of these "unfit" males as full citizens was never questioned in the public debate. The pattern of interpretation that tied military service to citizenship legitimated only the exclusion of women from political self-determination. ${ }^{13}$

On the other hand, one can understand the persistence of the Swiss gender order only in the context of contemporary sociopolitical and party-political constellations of power. The same is true for the situation of gender order in the respective warring nations. The introduction of women's suffrage in many nations following the world wars can be interpreted only partially as a reward for women's wartime sacrifice. As Richard Evans and Françoise Thébaud have argued, the granting of women's rights served primarily to restabilize the social order, which war had pushed to the brink. Evans and Thébaud thus interpret the introduction of women's suffrage as the ruling classes' attempt to alleviate the tensions that had developed out of the demands of the workers' movement in Europe and of the African Americans' and immigrants' civil rights movements in the United States. ${ }^{14}$ In Switzerland, however, a sociopolitical compromise was struck in the mid-1930s in order to unify the country in the face of the coming war. Reinforced by a distinct patriotism, the so-called Geistige Landesverteidigung (Spiritual defense of the nation) served as a common ground on which to settle the class antagonism of the interwar years and to incorporate the Social Democrats into the political power cartel.

Switzerland has a long tradition of bringing oppositional powers into government. Because of the Swiss democracy's ability to include a broad spectrum of political powers, the political scientist Arend Lijphart has characterized it as a model consensus democracy. Compared to the Anglo-Saxon majority democracies, Lijphart argues, the Swiss form of government is a "kinder and gentler" form of democracy.$^{15}$ There is considerable evidence for this assessment. Nevertheless, it cannot be taken as absolute, for throughout Swiss history it has been precisely the consensus between individual social groupings that has time and again excluded other segments of society from political power. In the first decades of the twentieth century, for example, the political bloc of Liberals, Catholic Conservatives, and the Farmers and Artisans Party was directed, above all, against the Social Democrats. And, as I will

${ }^{13}$ Wecker, "Es war nicht Krieg!" 43; Regula Stämpfli, "Triumph der Geschlechtertrennung in der Schweiz 1918-1945," in Dejung and Stämpfli, Armee, Staat, und Geschlecht, 226-27.

${ }^{14}$ Richard J. Evans, The Feminists: Women's Emancipation Movements in Europe, America, and Australasia, 1840-1920 (New York, 1977), 204-28; Françoise Thébaud, "Der Erste Weltkrieg: Triumph der Geschlechtertrennung," in Geschichte der Frauen: 20. Jahrhundert, ed. Françoise Thébaud (Frankfurt am Main and New York, 1995), 77-91.

${ }_{15}$ Arend Lijphart, Paterns of Democracy: Government Forms and Performance in Thirty-six Countries (New Haven, CT, 1999). 
show, the male solidarity of the 1930s that spanned the divisions of class politics was one reason why demands for economic and political equality for Swiss women found no resonance for so long in the postwar period. ${ }^{16}$

Men's experiences in the army during the war, especially their experience of military comradeship, were invoked repeatedly in the postwar period as the perfect symbol for the political compromise between Left and Right. As Ute Frevert has shown, the army is particularly well suited to serve as a laboratory for the establishment of sociopolitical models. Not only is it the one social institution in which the state monopoly on violence is legitimately concentrated; in addition, completion of military service is understood in many nation-states to be the requirement male adolescents must fulfill to become true men and full citizens. ${ }^{17}$ As Joanna Bourke has claimed, such "male bonding," in the context of the national institution of the army, is an "intimate, emotional interaction between men in which the individual identifies himself as an integral part of an all-male group. It implies a consciousness of masculinity as gender and although distinctions such as those based on class or ethnicity may be recognized, these distinctions are subordinated to the gender identity." 18

In what follows, I will show that after a power struggle in the Swiss officer corps, the military discourse on comradeship became a model for social compromise and that from this point on, the army was seen no longer as being in opposition to democratic society but, rather, as being part of it. Through this realignment, military discourse could link up with the ideology of Geistige Landesverteidigung and the army could become a symbol of national unity even for Social Democrats, who until then had been critical of the military. This social compromise, made within the framework of the military discourse on comradeship, applied exclusively to men and reinforced the discursive exclusion of women from the political sphere. It was in this context, beginning in the late 1930s, that various women's organizations tried to create the

${ }^{16}$ Over the long run, however, the Swiss consensus democracy seems to be quite capable of incorporating marginalized segments of society, including that of women. Thus, in 2008, women constituted 25 percent of the members of the Swiss national parliament, placing Switzerland above the average for Western industrialized nations according to an Inter-Parliamentary Union survey and well above the legislatures of majority democracies such as France (18.2 percent), Great Britain (19.5 percent), or the United States (17 percent). Leading the Western industrialized nations is Sweden, where 47 percent of the members of the national parliament in 2008 were women. See the entry for January 31, 2009, in the Women in National Parliaments section of the Inter-Parliamentary Union Web site, http://www.ipu.org/wmn-e/classif.htm.

${ }^{17}$ Ute Frevert, "Gesellschaft und Militär im 19. und 20. Jahrhundert: Sozial-, kultur-, und geschlechtergeschichtliche Annäherungen," in Militär und Gesellschaft im 19. und 20. Jahrhundert, ed. Ute Frevert (Stuttgart, 1997), 7-14.

${ }^{18}$ Bourke, Dismembering the Male, 127. 
preconditions for women's suffrage by introducing voluntary military service for women. This strategy proved unsuccessful, though, since (among other reasons) those who initiated the Women's Auxiliary Service fell into the dominant polarized gender order. Finally, I will show how Switzerland's army, because it had been spared active combat in the war, could take a prominent place in the national self-perception after 1945 that was equaled by no other European army in the postwar years. Consequently, the ideology of the Swiss national community was based to a large extent on the virtues of military comradeship, and this can be seen as one of the reasons Swiss women did not receive full political rights on the national level until 1971.

\section{GEISTIGE LANDESVERTEIDIGUNG AND THE Military-Political Realignment}

To understand why service in the Swiss army acquired the meaning it did after 1945, we must first look at the period before the outbreak of World War II. At the beginning of the 1930s, Switzerland was still a politically divided country. There was a wide gulf between the leftist parties and the bourgeois bloc of Liberals, the Farmers and Artisans Party, and the Catholic Conservatives. The army was partly responsible for this. In November 1918, Swiss labor unions and leftist parties had called for a general strike, to lend weight to their demands for an old-age pension, a forty-eight-hour workweek, women's suffrage, and the introduction of proportional representation in the national parliament. The general strike was the high point of a class confrontation that had been triggered by the Swiss government's unpreparedness for the consequences of the economic war after 1914. The food crisis caused by the war, as well as inflationary methods of financing the country's defense, impoverished wide segments of the population. Thanks to the export of war matériel and other sales opportunities, the industrial production system was able to recover, but the workers' movement was radicalized. ${ }^{19}$ To reestablish domestic order and suppress the general strike, the Swiss government deployed the army, which used force in the process. ${ }^{20}$ The memory of the general strikeand especially the fact that the army did not act as an apolitical peacekeeping power but, rather, used rightist militias to help secure the streets-poisoned the domestic political climate for more than a decade. For many members of

${ }^{19}$ Jakob Tanner, Valentin Groebner, and Sébastien Guex, "Einleitung: Kriegswirtschaft und Wirtschaftskriege, Forschungsperspektiven und Untersuchungsfelder," in Kriegswirtschaft und Wirtschaftskriege, ed. Valentin Groebner, Sébastien Guex, and Jakob Tanner (Zurich, 2008), 16.

${ }^{20}$ Willi Gautschi, Der Landesstreik 1918 (Zurich, 1968). 
the Left, the army appeared to be more an armed extension of the bourgeoisie in the social conflict than an instrument for defending the country. ${ }^{21}$

World War I also became a litmus test for the multilingual Swiss nation, since large numbers of German- and French-speaking elites sympathized with the neighboring country that spoke their language. The stance of the army leadership helped polarize this conflict. In particular, General Ulrich Wille, commander in chief of the Swiss army during World War I, was an outspoken supporter of Germany, a position that led to considerable indignation in the French- and the Italian-speaking parts of Switzerland. General Wille had also been primarily responsible for establishing new standards of military conduct after the turn of the century. For Wille, who followed Prussian training methods, civilians turned into soldiers through strict training and drilling were the foundation of the army. This transformation demanded absolute obedience and submission to the officers' strong leadership. Wille linked this fundamentally new vision of the military, which was to supplant the nineteenth-century Swiss republican image of the soldier as a citizen in uniform, to the model of gender duality. The development of military masculinity was elevated to a principle considered decisive for war, and military training was described as Erziehung zur Männlichkeit (training in masculinity). This concept remained dominant even after 1918. Wille's vision of military training, as well as the dogma of cultivating soldierly masculinity, shaped the military's basic training well into World War II. ${ }^{22}$

In the political thought of General Wille's disciples, however, the concept of military masculinity was more than just a means of bringing soldiers closer to the military's ideals. Military masculinity set the bar by which civil society was to be measured. But civil society could not satisfy the demands of discipline, rigor, and obedience placed on it by the military theoreticians of this new direction. Supporters of the new direction thus concluded that society as a whole had to become more authoritarian, soldierly, and masculine. Hence, many of General Wille's disciples, such the former chief of staff Emil Sonderegger, who had commanded the troops in Zurich during the 1918 general strike, and the division commander Eugen Bircher were active during the interwar years in the staunchly anti-Communist conservative militias that

${ }^{21}$ Hans Ulrich Jost, Die reaktionäre Avantgarde: Die Geburt der neuen Rechten in der Schweiz um 1900 (Zurich, 1992), 77-78; Rudolf Jaun, Preussen vor Augen: Das schweizerische Offizierskorps im militärischen und gesellschaftlichen Wandel des Fin de siècle (Zurich, 1999), 245; René Zeller, Emil Sonderegger: Vom Generalstabschef zum Frontenführer (Zurich, 1999), 96-97, 120-21.

22 Jaun, Preussen vor Augen, 311; Rudolf Jaun, "Militär, Krieg, und Geschlecht: Europäische Entwicklungslinien und schweizerische Besonderheiten," in Dejung and Stämpfli, Armee, Staat, und Geschlecht, 92; Gerhard Wyss, "Ulrich Wille und sein Einfluss auf die Ausbildung," in General Ulrich Wille: Vorbild den einen; Feindbild den anderen, ed. Rudolf Fuhrer and Paul Meinrad Strässle (Zurich, 2003), 181-99. 
formed in reaction to the general strike. These disciples greeted the rise of the politically authoritarian regimes in Italy and Germany with the greatest sympathy and welcomed the rise of the extreme right-wing Frontenbewegung (fascist movement) in Switzerland. ${ }^{23}$

The most prominent advocate in the 1930s and 1940s of a society grounded in soldiership was Colonel Gustav Däniker, whose ideal was an authoritarian soldier's state. In 1940 he wrote: "Unconditional integration is unworthy of a free Swiss[,] and ... behind the reference to 'citizens in uniform' is often hidden a demand of democratic citizens for concessions." Däniker was against any such concessions. In his view, the central goal of military training was obedience, and since the army was supposed to be the spiritual basis for the political realignment of the state, the creation of obedient citizens was, he believed, absolutely necessary for the survival of the Swiss nation. To bolster what in his opinion was an inadequate military power, Däniker extolled "true soldiership" and advocated domestic and foreign policies that accommodated the "new"- that is, National Socialist-Europe. ${ }^{24}$ These views, however, placed General Wille's disciples on the outer fringe of Swiss politics in the late 1930s.

In the shadow of the 1933 National Socialist seizure of power in Germany and amid increasing fear of a renewed European war, a political compromise in the name of patriotism was effected in Switzerland across the country's different regions that was tagged with the slogan of Geistige Landesverteidigung. This compromise did not, of course, completely do away with the old political contradictions; it represented a minimal political consensus, born of necessity and laboriously maintained. All the same, this consensus eased the class-political conflict that had been so virulent since the end of the nineteenth century. ${ }^{25}$ The question of the army played an important role in Geistige Landesverteidigung. In 1937, in view of the military buildup in Italy and Germany and the wars in Abyssinia and Spain, the Social Democratic Party-

${ }^{23}$ See Beat Glaus, Die Nationale Front: Eine Schweizer faschistische Bewegung 1930-1940 (Zurich, 1969), 59-60; Daniel Heller, Eugen Bircher: Arzt, Militär, und Politiker; Ein Beitrag zur Zeitgeschichte (Zurich, 1990); Jost, Die reaktionäre Avantgarde; Willi Gautschi, General Henri Guisan: Die schweizerische Armeeführung im Zweiten Weltkrieg (Zurich, 1994); Zeller, Emil Sonderegger, 184-223.

${ }^{24}$ Gustav Däniker, Werdendes Soldatentum (Bern, 1940), 49-50, 51. See also Gautschi, General Henri Guisan, 396.

${ }^{25}$ Josef Mooser, "Die 'Geistige Landesverteidigung' in den 1930er Jahren: Profile und Kontexte eines vielschichtigen Phänomens der schweizerischen politischen Kultur in der Zwischenkriegszeit," Schweizerische Zeitschrift für Geschichte 47 (1997): 685-708; Hansjörg Siegenthaler, "Die Rede von der Kontinuität in der Diskontinuität sozialen Wandels: Das Beispiel der dreissiger Jahre," in Schweiz im Wandel: Studien zur neueren Gesellschaftsgeschichte; Festschrift für Rudolf Braun zum 60. Geburtstag, ed. Sebastian Brändli and Rudolf Braun (Basel and Frankfurt am Main, 1990), 414-39. 
which up to this time had been extremely critical of the army-not only renounced the principles of class conflict but even declared its unconditional support for the military defense of the nation. This was an essential condition for making the Social Democratic Party acceptable to the bourgeois parties and thus a political partner, and in 1943, for the first time, a Social Democrat became a member of the seven-headed government. The Social Democrats' change of course on the question of the army was connected to a series of their own demands, which were met to a large extent in the first years of the war: the purging of fascist officers from the army, salary compensation for mobilized soldiers, a socially acceptable financing of the military buildup, and a leveling of the playing field for all levels of the population as regarded military careers. ${ }^{26}$

Even the tensions between the different regions of the country were to a large extent resolved in the late 1930s. Innumerable propaganda writings and public events like the 1939 National Exhibition in Zurich invoked national unity. Cultural differences between the linguistic regions and also between urban and rural areas were said to have been resolved through the idea of Switzerland as a Willensnation (nation of will), which was supposed to unite the different population groups under one national roof. ${ }^{27}$ But there was another side to the Geistige Landesverteidigung ideology. Hans Ulrich Jost, for example, detects a distinct smell of Blut und Boden ("Blood and Soil") behind the constant evocations of the Swiss Volksgemeinschaft (people's community). For Jost, then, Geistige Landesverteidigung is the equivalent of a "Helvetic totalitarianism" that was open to antisemitic and antisocialist patterns of interpretation. ${ }^{28}$ Scholars such as Kurt Imhof and Oliver Zimmer oppose this thesis, seeing Geistige Landesverteidigung as an "antitotalitarian foundational compromise" and pointing to the domestic reforms of the time..$^{29}$ But whatever the case, the widespread rhetoric in the 1930s deploring the "overforeignization" and "Judaization" of Switzerland, as well as the restric-

${ }^{26}$ Marco Zanoli, Zwischen Klassenkampf, Pazifismus, und Geistiger Landesverteidigung: Die Sozialdemokratische Partei der Schweiz und die Wehrfrage 1920-1939 (Zurich, 2003), 227-28.

${ }^{27}$ Oliver Zimmer, "“A Unique Fusion of the Natural and the Man-made': The Trajectory of Swiss Nationalism, 1933-39," Journal of Contemporary History 39 (2004): 5-24.

${ }^{28}$ Hans Ulrich Jost, "Bedrohung und Enge (1914-1945)," in Geschichte der Schweizund der Schweizer, ed. Ulrich Im Hof and Beatrix Mesmer, 3 vols. (Basel, 1982-83), 3:174-75.

${ }^{29}$ Kurt Imhof, "Das kurze Leben der geistigen Landesverteidigung: Von der 'Volksgemeinschaft' vor dem Krieg zum Streit über die 'Nachkriegsschweiz' im Krieg," in Konkordanz und Kalter Krieg: Analyse von Medienereignissen in der Schweiz der Zwischen- und Nachkriegszeit, ed. Kurt Imhof, Heinz Kleger, and Gaetano Romano (Zurich, 1996), 19-83; Oliver Zimmer "Die 'Volksgemeinschaft': Entstehung und Funktion einer nationalen Einheitssemantik in den 1930er Jahren in der Schweiz," in ibid., 85-109. 
tive wartime refugee policy that was responsible for turning away thousands of Jewish refugees, many of whom as a result met their deaths in National Socialist extermination camps, can be seen as the other side of the unitycreating discourse of Geistige Landesverteidigung. ${ }^{30}$

In the fall of 1939, when the Swiss parliament elected the French Swiss Henri Guisan general and thus commander in chief of the army, ${ }^{31}$ Geistige Landesverteidigung was realized in the army as well. Of particular importance was the fact that Guisan's rival for the post of general was Ulrich Wille Jr., the son of the World War I commander in chief General Ulrich Wille-and, like his father, an ardent admirer of the German military character and a fan of the Wehrmacht. Beginning in October 1906, as part of his advanced military training, the younger Wille spent a year with the royal Prussian Garde-Jäger Battalion in Potsdam. ${ }^{32}$ After the election of Guisan, Wille Jr. and his supporters increasingly lost ground, and during the first years of World War II there was a struggle for power in the general staff between Guisan and General Wille's disciples. Guisan's most important opponents-Wille Jr., Däniker, and Bircher-were forced into retirement, and others, like Chief of Staff Jakob Labhart, were transferred to less important positions. ${ }^{33}$ During the war, Guisan enjoyed the almost unlimited trust of the population-not least because of the army report he issued on the legendary Rütli-Wiese (the site at which the first League of the Three Forest Cantons was formed in 1291), where he announced Switzerland's unconditional will to resist militarily any would-be attackers. With this avowal in July 1940, which was publicly broadcast in the media, Guisan set an example against the paralysis in domestic politics that had beset broad swathes of the population, including the military and political leadership, after the swift and unexpected defeat of the French army by the Nazis. ${ }^{34}$

The military training reforms made under Guisan were also welcomed by

${ }^{30}$ See Unabhängige Expertenkommission Schweiz-Zweiter Weltkrieg [Independent commission of Swiss experts-World War II], Die Schweiz und die Flüchtlinge zur Zeit des Nationalsozialismus (Zurich, 2001); Patrick Kury, über Fremde reden: überfremdungsdiskurs und Ausgrenzung in der Schweiz, 1900-1945 (Zurich, 2003).

${ }^{31}$ In contrast to other armies, the army of Switzerland has no rank of general in peacetime. Only in wartime is a general elected and the post of commander in chief of the armed forces thereby filled.

${ }^{32}$ Niklaus Meienberg, Die Welt als Wille und Wahn: Elemente zur Naturgeschichte eines Clans (Zurich, 1987), 67-75.

${ }^{33}$ Georg Kreis, Auf den Spuren von La Charité: Die schweizerische Armeeführung im Spannungsfeld des deutsch-französischen Gegensatzes 1936-1941 (Basel and Stuttgart, 1976), 180-83.

${ }^{34}$ The spiritual crisis of the summer of 1940 and its overcoming are portrayed in Jakob Tanner, “'Die Ereignisse marschieren schnell': Die Schweiz im Sommer 1940," in Struktur und Ereignis, ed. Andreas Sutter and Manfred Hettling (Göttingen, 2001), 257-82. 
large segments of the population. While General Wille's disciples had striven for a militarization of civilians, under General Guisan an actual civilizing of the military was effected, ${ }^{35}$ a change that broke with the training methods that had dominated the Swiss army since the end of the nineteenth century. Guisan was skeptical of the Wille-inspired military mode, which he viewed as "playing soldier," and, in contrast to Wille, came out strongly for the republican model of the citizen soldier. In the spring of 1941 he ordered his chief of staff to prepare a report that would "deplore and condemn the 'staccato' and other aberrant ways of speaking and drilling, such formal excesses." 36 In a speech delivered in 1943, he called for the newly appointed corps, division, brigade, and regiment commanders always to remember that their subordinates were men who "have hopes and cares, men who have a family of their own and a career and a place in life." He urged his commanders in leading "these men, our soldiers," to combine "strictness with humanity." 37

The reforms introduced under Guisan were an expression of the army's new political self-understanding. Many military-theory texts of this era emphasize the importance of democracy and express categorically the position that, in the end, the army is subordinate to the democracy. This was characterized not as a flaw but as a mark of the quality of the Swiss army. Thus, a contributor to the 1944 Festschrift for Guisan could write: "Yes, the general is elected, not appointed, not promoted, but elected. ... The people elects its general! That is the proudest conclusion of democratic thought, that even in soldierly matters and in the country's hour of need we preserve the sovereignty of the citizen in a momentous decision and leave the determination of the leadership of the troops to the free discretion of the representatives of the people." 38

By contrast, officers who called for a military training of blind obedience or that spoke of civil society with contempt were seldom heard after 1940. With authoritarian regimes to the north and south of the country, developing independent citizens of the state as opposed to blindly obedient soldiers was seen as one of the main goals of Swiss military training. For example, the brochure Swiss Youth and the Defense of the Country (Schweizer Jugend und Landesverteidigung), which contained supplementary material for an essay contest carried out under Guisan's auspices, explains that "for us the soldier

${ }^{35}$ For a discussion of these two possible relationships between the military and civil society, see Ute Frevert, Die Kasernierte Nation: Militärdienst und Zivilgesellschaft in Deutschland (Munich, 2001), 297.

${ }^{36}$ Bernard Barbey, Fünf Jahre auf dem Kommandoposten des Generals: Tagebuch des Chefs des Persönlichen Stabes General Guisans 1940-1945 (Bern, 1948), 77-78.

${ }^{37}$ General Henri Guisan, address of December 28, 1943, to the newly appointed corps, division, brigade, and regiment commanders, given on the Sempach battlefield, in Dokumente des Aktivdienstes, ed. Hans Rudolf Kurz (Frauenfeld, 1965), 133.

${ }^{38}$ Gottlieb Trachsel, "Fahneneid und Landesverrat," in Bürger und Soldat: Festschrift für Henri Guisan, ed. Schweizerische Offiziersgesellschaft (Zurich, 1944), 122. 
is not an end in himself. The soldier is only the means to secure the possibility of remaining free citizens.... That's why training to become a soldier means for us first and foremost training to become a good citizen. In Switzerland no one is just a solider but a soldier and a citizen." 39 This line of thought conceived the citizen of the state exclusively as a man. In contrast to men, who had to perform military service, women did not receive or profit from the civic training that military service claimed to provide; thus, they clearly lacked essential prerequisites for participation in political life.

\section{The Comradeship Ideology and Sociopolitical Compromise}

It would be false to conclude, however, that all the officers surrounding Guisan were ardent champions of democracy. Guisan himself was an admirer of Mussolini and, like many members of the bourgeoisie, had long been extremely distrustful of the political Left. ${ }^{40}$ But in contrast to General Wille's disciples, who were never able to overcome the trauma of the general strike, Guisan knew how to accommodate the Social Democrats' new stance on defending the country. The Social Democrats reciprocated, rewarding Guisan for his openness with unreserved support. ${ }^{41}$ Guisan thus realized the same social compromise in the army that had been effected in the political and cultural realms under the flag of Geistige Landesverteidigung.

The concept of masculinity also played a significant role in the worldview of the officers around Guisan. Theirs was not, however, the harsh, authoritarian masculinity of Wille's new direction but a masculinity of comradeship that was mindful of social compromise and that was to be realized in the republican form of the citizen soldier. The idea of the citizen soldier worked quite well with the ideology of comradeship. It is true that for General Wille and his disciples comradeship was also a central aspect of the military system of order, though first and foremost as an ideology for making soldiers into an obedient collective; 42 Guisan, however, gave the idea of comradeship a fundamentally new, republican meaning. The general himself used this concept to characterize his relationship with his subordinates, putting himself, at least rhetorically, on the same level as his soldiers. This is illustrated by his choice

${ }^{39}$ Sektion Heer und Haus, ed., Schweizer Jugend und Landesverteidigung: SchweizerwocheAufsatzwettbewerb 1943; In den Schulen des Landes, mit Ermächtigung der kantonalen Unterrichtsdirektionen und unter dem Patronat von General Guisan, Oberbefehlshaber der Armee (Bern, 1943), 53, 57.

${ }^{40}$ Gautschi, General Henri Guisan, 54-55; Tanner, “'Die Ereignisse marschieren schnell,", 268-69.

${ }^{41}$ Gautschi, General Henri Guisan, 605-15.

${ }^{42}$ See, e.g., Werner Kobelt, "Ein Beitrag zu den Grundfragen der Offizierserziehung," in Festschrift für Ulrich Wille: Zum 60. Geburtstag (Zurich and Leipzig, 1937), 184. 
of words in the last army report (on August 19, 1945) he gave to his subordinates: "I remain your older comrade, to whom you may turn to talk about what's on your mind, and who will always gladly receive you and give you advice." 43 Major Robert de Traz was thus consistent with Guisan's own self-understanding when he wrote in the 1944 Festschrift for Guisan that "it would not be disrespectful — on the contrary - to say that the General is every soldier's comrade." ${ }^{44}$ In such sentiments Guisan got along exceptionally well with the Swiss soldiers, who were incredibly hostile to the military drills of the Wille school and for whom comradeship played an extraordinarily large role. ${ }^{45}$

Comradeship is a concept found in all modern armies whether the army is at war or at peace. From a gender-history perspective, it is interesting to note that comradeship also presents aspects that seem diametrically opposed to the idea of soldierly masculinity. As Thomas Kühne has shown, the ideal of military comradeship consists in a family-like security, in an affectionate, even motherly masculinity. Military comradeship thus displays characteristics that in the traditional gender dichotomy count as "feminine" and therefore stand in glaring contradiction to such "masculine" qualities as courage, toughness, and self-control that in many propagandistic writings characterize the essence of what it is to be a soldier. ${ }^{46}$ Soldiers were supposed to be utterly fearless warriors who were also able to listen to, support, and console their comrades. Thus, the 1940 Soldatenbriefe (Soldiers' letters), written by a solider, declares: “A soldier's heart should be hard as steel in the hour of danger. But it should also be tender and kind when a comrade needs his help and sacrifice." ${ }^{47}$ This tender, comradely side of soldierly masculinity was important because it gave soldiers in the army emotional security and enabled them to bear the burdensome demands of military operations. It was precisely the exclusion of women from the army that led to the need for soldiers to take on qualities and activities that have a more feminine connotation in civilian life. Nevertheless, the tender, comradely masculinity was never characterized

${ }^{43}$ Henri Guisan, Bericht an die Bundesversammlung über den Aktivdienst 19391945 (Bern, 1946), 239.

${ }^{44}$ Robert de Traz, "Sur la camaraderie," in Schweizerische Offiziersgesellschaft, Bürger und Soldat, 396.

${ }^{45}$ See Christof Dejung, Aktivdienst und Geschlechterordnung: Eine Kultur- und Alltagsgeschichte des Militärdienstes in der Schweiz, 1939-1945 (Zurich, 2006), 165240.

${ }^{46}$ See Thomas Kühne "“... aus diesem Krieg werden nicht nur harte Männer heimkehren': Kriegskameradschaft und Männlichkeit im 20. Jahrhundert,” in Männergeschichte, Geschlechtergeschichte: Männlichkeit im Wandel der Moderne, ed. Thomas Kühne (Frankfurt am Main and New York, 1997), 174-92; Kühne, "Der Soldat," 351-55.

${ }^{47}$ Jakob Brütsch, Soldatenbriefe (Schaffhausen, 1940), 38. 
as feminine - the concept of the feminine was clearly negative in a military context and served to denigrate actions and ways of thinking deemed undesirable. Qualities such kindness and readiness to sacrifice, which in civil life were associated with the feminine, were considered an expression of masculinity in the context of military comradeship. Thus, we find this passage in a memoir of the first months of the war: "During those long four months . . . we all experienced how soldiers living side by side became men living for each other. When we think back on those times, we have not only unforgettable memories of difficult hours and days but also the image of understanding, kind, and devoted comrades." This comradeship "is the product of an open, upright masculinity." 48

Fundamentally new to military discourse was the view that the idea of comradeship should not remain confined to the army. A 1941 propaganda piece, for example, called for the Swiss population to become under the threat of the current war a "people of soldiers and comrades." 49 This notion of national unity under the flag of comradeship was meant to apply to the social arena as well. This points to a remarkable difference between Switzerland and some other countries where the regeneration of society through the adoption of the ideal of male bonding and the formation of comradely communal relationships was understood to be contrary to parliamentary democracy and modern society. This was the case first and foremost in National Socialist Germany. For National Socialism, comradeship meant that the individual fit like a perfect $\operatorname{cog}$ in the machinery of society and unconditionally subordinated himself to the commands of his leader. ${ }^{50}$ In Switzerland, by contrast, forming a community of able-bodied men through male bonding was understood to be a voluntary act that, according to the contemporary discourse, constituted the basis for the formation of the confederated community of the Swiss nation. The symbol of this view was the confederate founding myth of the Rütlischwur of 1291, the oath with which the leaders of three valleys formed an alliance against oppressive Austrian rule. Thus, the concept of comradeship could indeed serve Switzerland as a discursive means for promoting democratic self-determination and sociopolitical compromise. For example, when the Catholic Conservative federal councilor Philipp Etter gave a programmatic speech on Geistige Landesverteidigung in 1937, he counted, in addition to multilingualism and a reverence for the dignity and freedom of

${ }^{48}$ Gebirgs-Füsilier-Bataillon 43, Weihnachten im Felde 1939 (Lucerne, 1939 ), 17.

${ }^{49}$ Eugen T. Rimli, ed., Soldaten Kameraden: Erinnerungsbuch an die Mobilmachung und den Aktivdienst 1939/41 (Zurich, 1941), vii.

${ }^{50}$ Richard Evans, Comrades and Sisters: Feminism, Socialism, and Pacifism in Europe, 1870-1945 (Basingstoke, 1987), 159; Thomas Kühne, Kameradschaft: Die Soldaten des nationalsozialistischen Krieges und das 20. Jahrhundert (Göttingen, 2006), 100-101. 
human beings, the "affirmation of an armed defense of the nation" and the notion of being a "confederated community" as the constants of Switzerland's national self-understanding. ${ }^{51}$

The idea of comradeship also motivated men in the army to support fellow soldiers who found themselves in economic difficulties as a result of performing their military service. Thus, we find this passage in a soldier's memoir of his first year of active service 52 (the net proceeds from which would be used for soldiers' welfare assistance): "There are comrades among us who need our urgent support so their families won't suffer hardship at home. ... Our comrades who live in difficult financial situations must not lose faith in the homeland, faith in their fellow man. . . . Remember our motto: All for one and one for all!'53 Many military-theory writings of the wartime period argued that social tensions had to be eased because otherwise they would weaken the combat strength of the Swiss army. It was thus in the army's interests that social problems be addressed. The 1943 brochure Swiss Youth and the Defense of the Country stated that solidarity among the people should also positively affect Swiss military strength, for in Switzerland "the soldier should never have the feeling that he's only protecting the wallet of the rich and not the country and the people. Switzerland must be a special democracy. ... Material want must not let any citizen despair of the ideal values of the confederacy." ${ }_{54}$ And in the 1944 Festschrift for Guisan, one contributor opined that social justice would support the defense of the nation and that the army leadership must therefore do everything it could in the realm of military training to promote social compromise: "Nothing harms combat strength and the military attitude as much as social tension and domestic political conflict in which one segment of the population believes itself to be constantly put in its place and neglected." Policy, especially economic and social policy, would therefore exert the greatest influence on the Swiss people's attitude toward the army in the postwar era: "The more balanced our social conditions are, the more willingly will Switzerland take on the most difficult personal and financial burdens for the defense of the nation." ${ }_{55}$ When we realize that only

${ }^{51}$ Philipp Etter, Geistige Landesverteidigung: Vortrag gehalten in der Versammlung des Vaterländischen Verbandes des Kantons Bern am 29. Januar 1937 (Immensee, 1937), 8-9, 11.

52 The concept "active service" has been used in Switzerland since the end of the nineteenth century and is different from the regular training that takes place in military schools or yearly refresher courses. "Active service" in Switzerland refers to military service performed to maintain Swiss independence against foreign enemies or to uphold law and order within the country.

${ }^{53}$ Brütsch, Soldatenbriefe, 6.

${ }^{54}$ Sektion Heer und Haus, Schweizer Jugend und Landesverteidigung, 56.

${ }^{55}$ Fritz Wanner, "Gedanken zur schweizerischen Wehrpolitik," in Schweizerische Offiziersgesellschaft, Bürger und Soldat, 281. 
a few years earlier onetime or even active officers such as Eugen Bircher or Emil Sonderegger - both supporters of the Wille school-meddled in day-today politics with their anti-Marxist rhetoric of class struggle and thereby gave credence to the Left's image of the army as the bodyguard of the bourgeoisie, we can appreciate the great significance Guisan's election and victory in the debate with Wille and Däniker had for domestic politics.

The commitment to social compromise was tied to concrete sociopolitical reforms, many of which were gradually realized during the war. As it became clear that wartime military service would last longer than a couple of weeks - a duration many had secretly hoped for in 1939-many soldiers began to worry about their economic futures. ${ }^{56}$ The mobilization in September 1939 had torn 430,000 soldiers and 200,000 men in the auxiliary service away from their civilian lives. These men had to leave their jobs without knowing when, or if, they would return to them. The situation changed in 1940 after the defeat of the French, when a system of tours of duty was instituted in which conscriptable men would alternately be on active duty for several months and then be released for several months before having to reenlist. During this period, between 75,000 and 150,000 soldiers were mobilized. But even these soldiers had to interrupt their civilian activities for several months each year until the war ended, which time and again led to occupational and economic hardships. Being away from their farms posed a problem for farmers, for example, as family members and hired hands remaining on the farm could manage the workload only with difficulty. Farmers therefore often received vacation leave. Because of their frequent absence from their universities, soldiers who wanted to complete a higher education had problems taking the required exams. As a result, some had to give up their dreams of a university degree. And with the start of each new tour of active duty, employees and the self-employed had to fear losing their jobs on account of their military service or, because of a loss of income, being unable to pay the rent.

The governmental authorities, too, were concerned with soldiers' economic problems. Fear of social unrest resulting from unemployment or poor economic conditions had been ever present since the general strike of 1918 . There was therefore during World War II an attempt to learn from the sociopolitical mistakes of World War I. Numerous precautions were taken to maintain social security. In December 1939 a wage-and-income-compensation law was introduced. This took the place of the previous system of emergency aid, which, because of its nature as a welfare program, had been quite unpopular. In the new system, soldiers had the right to claim partial compensation for loss of income caused by their active service, regardless of their income or assets.

${ }^{56}$ Hans Senn, Anfänge einer Dissuasionsstrategie während des Zweiten Weltkrieges (Basel and Frankfurt am Main, 1995), 193. 
The new law was based on the notion of solidarity: employees, employers, and the public paid into the central soldiers' compensation fund from which mobilized soldiers and their families were paid. In addition, a new law protected soldiers' jobs, and throughout the entire war, men recruited because of the war were required to give only four days' notice to their employers. ${ }^{57}$ With all these sociopolitical measures, the Swiss government succeeded in substantially reducing the social conflict that could have resulted from active military service.

\section{The Polarization of the Gender Order and the Demand for WOMEN'S RIGHTS}

With Geistige Landesverteidigung and the persistent threat of a German invasion, the Swiss army achieved a hitherto unknown level of approval in Swiss society. As a result, the model of the soldierly man became dominant. But this model needed a female counterpart that would admire the soldiers and let herself be protected by them. As in other modern states, in Switzerland too the threat of war led to a polarization of gender characteristics, and the resulting polarized gender order constituted a central element of Switzerland's domestic order. ${ }^{58}$ This is illustrated by the thoughts expressed in a 1944 marriage advice book: "The soldier is a masculine man who fears nothing, who risks his life for the ideals of freedom and the fatherland. . . The woman feels clearly and surely that without these masculine spiritual goods she would not be able to fulfill her duties as a homemaker and mother. Thus the soldier is for her the indispensable, the complete man." 59

In the face of this polarized gender order, women demanding emancipation found themselves in an increasingly difficult position. In the mid-1930s, Swiss women's organizations undertook a fundamental change of course. Under pressure from a rising National Socialism, they decided to set aside their demands for women's suffrage and to work for the Swiss "people's community." For many women's rights activists this was a painful about-face. In order to defend the democratic form of government, they supported the very democracy that had denied them a political say for decades, and all feminist demands, such as those for political and economic equality, receded behind

${ }^{57}$ Regula Stämpfli, Mit der Schürze in die Landesverteidigung: Frauenemanzipation und Schweizer Militär 1914-1945 (Zurich, 2002), 199; Wecker, "Es war nicht Krieg!" 37-38; Kurz, Dokumente des Aktivdienstes, 53-55.

${ }^{58}$ See Hagemann and Schüler-Springorum, Home/Front; Thébaud, "Der Erste Weltkrieg," 52; see also Karin Hausen, "Die Polarisierung der 'Geschlechtscharaktere': Eine Spiegelung der Dissoziation von Erwerbs- und Familienleben," in Sozialgeschichte der Familie in der Neuzeit Europas, ed. Werner Conze (Stuttgart, 1976), 363-93.

${ }^{59}$ Heinrich Hanselmann, Werktag in der Liebe und Ehe (Zurich, 1944), 155. 
the pledge of national solidarity. Even progressive women's organizations in the early 1930s thus let themselves be integrated into a community whose gender models had extremely conservative characteristics. ${ }^{60}$ Nevertheless, the demand for women's equality was not taken completely off the table. In the late 1930s, after all, two referendums for women's right to vote at the cantonal level were introduced in the cantons of Geneva and Neuenburg-but were rejected, in the end, by the male voters. ${ }^{61}$

With their integration into the national consensus, and especially with their readiness to actively support the military defense of the nation, the women of the progressive wing of the women's movement hoped to prepare the ground for later political equality. ${ }^{62}$ They thus followed a strategy similar to that of the Social Democrats, who were able to achieve sociopolitical reforms and greater participation in political power in return for their support of military defense and the renunciation of class struggle. For progressive women's organizations, too, the question of the army was thought to be a key to attaining political equality. Because in Switzerland's republican tradition active civil rights were traditionally bound to military service, by the end of the 1930s the Swiss Union for Women's Suffrage saw in compulsory military service for women a possible way to prepare the ground for women's suffrage on the federal level. In 1938 the Schweizer Frauenblatt (Swiss women's journal) explored for the first time the idea of expanding compulsory military service to include women. The journal's argument drew on existing plans that would broaden compulsory service to include men unfit for regular military duty by drafting them into the newly restructured military auxiliary service. The extension of compulsory auxiliary service to women seemed to the editors of the women's journal the easiest way to clear a path for women into the army. The women's rights activists explicitly linked their readiness to serve the military with the demand for equal political rights: "We see in the recognition of the woman as an active citizen one of the most important preconditions for the awakening of all of women's abilities and their utilization for the new tasks." 63

The federal authorities and the army leadership, however, remained skeptical of this idea for a long time. It is quite possible that the authorities' hesitation stemmed from the women's unions' linking of their readiness to serve the military to their demand for political equality. In his 1959 memoir,

${ }^{60}$ The Swiss women's movement is not a special case in this regard. As Richard Evans has shown, women's movements in practically all industrial states moved to nationalistic-conservative positions in the interwar period as party politics became increasingly polarized. See Evans, The Feminists, 210-11.

${ }^{61}$ Mesmer, Staatsbürgerinnen ohne Stimmrecht, 269-70.

${ }^{62}$ This process of the "nationalization of women in the interwar period" is described in Stämpfli, Mit der Schürze in die Landesverteidigung, 84-104; and in Hardmeier, Frühe Frauenstimmrechtsbewegung in der Schweiz, 324-27.

${ }^{63}$ Schweizer Frauenblatt, December 16, 1938. 
Ernst Vaterlaus, formerly the head of the Women's Auxiliary Service (Frauenhilfsdienst, or FHD), writes indignantly about the idea that the service was “misused by certain women's organizations as propaganda for women's suffrage." 64 Because the military at that time still did not want women among its ranks, the progressive segment of the organized women's movement decided, at the end of the 1930s, to form its own organization, in which women could contribute to the defense of the nation. Under the direction of the Zurich women's rights activist and businesswoman Else Züblin-Spiller, the civilian FHD was founded in 1939. This organization was to coordinate all cantonal and local women's organizations as well as the many individual women who had offered their assistance in defending the nation if war broke out. The civilian FHD was thus neither an association nor a union but, instead, "a loose grouping of all Swiss women prepared to help," as a 1947 memoir of the civilian FHD puts it. ${ }^{65}$ At first the authorities were anything but pleased, as they suddenly had to deal with work applications from women's organizations and newly formed service unions. But the work that women didunpaid, with such devotion-in caring for soldiers, assisting refugees, working in agriculture, and bolstering the morale of the population and the soldiers soon made the skepticism vanish, and after the war began, these activities helped win wide recognition for the contributions made to the war effort by women's organizations. ${ }^{66}$

The FHD's Dienstbüchlein für den Alltag der Schweizerin (Employment booklet for the Swiss woman's everyday routine) shows how the women's unions themselves understood the role of Swiss women in "fulfilling their duties to the fatherland." This book assigns women the responsibility for engendering the patriotism of Swiss women and men: "Every good mother helps to establish and improve the Swiss home. The living room is our world; it might be small, but it grows large as a school of morals, as the school of future citizens of the state." In another passage, the booklet calls on "Woman and mother [to] place your own self and desires in the background, [and] show an interest in the soldier's concerns, even if his descriptions of the soldier's life appear strange to you." 67 The founders of the civilian FHD thus promulgated an image of women similar to the one that predominated among the governmental authorities and broader public. The brochure Swiss Youth and

${ }^{64}$ Ernst Vaterlaus, "Der Frauenhilfsdienst in unserer Armee im Aktivdienst 19391945," in Die Schweiz im Zweiten Weltkrieg: Das grosse Erinnerungsbuch an die Aktivdienstzeit, 1939-1945, ed. Hans Rudolf Kurz (Thun, 1959), 331.

${ }^{65}$ Gertrud Haemmerli-Schindler, Zürcherfrauen erleben den Zivilen Frauenhilfsdienst 1939-1945: Neujahrsblatt der Hülfsgesellschaft in Zürich auf das Jahr 1947 (Zurich, 1947), 8.

${ }^{66}$ Stämpfli, Mit der Schürze in die Landesverteidigung, 144-53.

${ }^{67}$ Schweizerischer Ziviler Frauenhilfsdienst, ed., Treu der Heimat: Dienstbüchlein für den Alltag der Schweizerin; Worte zur innern Haltung (Zurich, 1941), 12-13. 
the Defense of the Country, which was published under the auspices of General Guisan, also presented the view that the Swiss woman had to make sure 'that her male comrades' understanding of and spirit of sacrifice for military preparedness remain awake. It is the responsibility of daughter, sister, spouse, and wife that the national consciousness not fade in a single house, in a single family." Only a country that cultivated such women could stand "strong in the storms of life." ${ }^{68}$ Both texts emphasize that preparedness for military defense depends first and foremost on men and women faithfully fulfilling their respective tasks. The survival of the Swiss nation was thus made to depend directly on the stability of the contemporary gender order.

The image of women that appears in these sources does only partial justice to the actual activities in which women were engaged. Due to men's absence while serving in the military during the war, many women worked jobs that in peacetime were considered completely masculine. Women also performed new tasks in industry, agriculture, administration, and the service sector. Most often, however, they worked in family businesses or on their own farms, doing work that became available with the absence of the men. These female fields of activity played a subordinate role in the contemporary discourse, and women's work did not even appear in the official statistics, which included only long-term employment (since a woman's entry into the workplace was often temporary and ended when men returned to their old positions). Recognition of women's extensive participation in Switzerland's wartime economy was thus both legally and discursively guarded against in such a way that the dominant gender order was never in danger. The image of the man as the family's provider was thus maintained, even in the exceptional situation of the war. ${ }^{69}$

But women not only supported the army on the home front; they also undertook valuable support jobs within the fighting forces. The creation, in 1940, of the military FHD exemplifies the difficulty of integrating women into the male space of the army when they did not fit the classic mother and hausfrau roles. Just as was the case with the civilian FHD, women in the military FHD were incorporated into the army only because of the initiative of the women's unions. In the spring of 1939, women's unions, which had already offered to serve the military, reacted disappointedly to the authorities' lack of concrete suggestions for incorporating women into the army. Individual cantonal women's unions therefore began to give their members registration forms, which women could fill out and have sent to the cantonal or federal military authorities. ${ }^{70}$

This strategy met with success. In February 1940, Guisan issued guidelines

${ }^{68}$ Sektion Heer und Haus, ed., Schweizer Jugend und Landesverteidigung, 62-63.

${ }^{69}$ Wecker, "Es war nicht Krieg!" 29-46.

${ }^{70}$ Stämpfli, Mit der Schürze in die Landesverteidigung, 164-66. 
for the organization of the FHD, which stipulated that the women who had registered for the military FHD were to undergo a health exam and that if they were declared fit for military service, they would be considered to have an auxiliary service duty and would be subject to military law until the end of the war. Yet the army leadership was insistent that no one think that the women who performed military service were to be placed on equal footing with the male members of the military: "There will be no women's army," declared the April 10, 1940, Aufruf an die Schweizerfrauen (Call to Swiss women) to register for the military FHD: "There is no question of women serving with weapons. Neither will a uniform be issued; however, we will aim for consistent dress." 71

Between 1940 and 1945 there were continually between 18,000 and 23,000 FHD members performing military service. They were employed as drivers, aircraft spotters, orderlies, and office assistants. ${ }^{72}$ Their experiences were quite varied. Some recounted that their superiors, who eventually regarded them quite well and highly valued their efforts, were initially somewhat skeptical of the young women. ${ }^{73}$ Other FHD members, by contrast, complained time and again of the critical and even dismissive comments made by soldiers and officers and the often disdainful treatment they received. ${ }^{74}$ The fact that women FHD members had broken into a field with clear male connotations made many people suspicious. Thus, many ex-FHD members reported that during the war they were continually confronted with the assumption that they had joined the army only to find a man. And as one ex-FHD member reports, FHD members were even to some extent known in public as "officers' sluts."75 This has been confirmed by another female contemporary who also remembers such calumnies. She differentiates, however, between the appreciation shown by her superior officers and some civilians' negative reactions: "But there was a lot of hostility in Switzerland. The men and young boys, they even

${ }^{71}$ Aufruf an die Schweizerfrauen, 10.4.1940, Schweizerisches Bundesarchiv [Swiss Federal Archives], Bern (BAR), E 5795/279.

${ }^{72}$ Hans Rudolf Kurz, Die Geschichte der Schweizer Armee (Frauenfeld, 1985), 139.

${ }^{73}$ Interview with Liselotte F., May 3, 2000. The interviews quoted in this essay come from the Oral-History-Projekt Archimob (http://www.archimob.ch), in which I played an active role. The project interviewed over five hundred Swiss men and women who lived through World War II about their experiences during the war. The interviews have been given to the Bern Historical Museum and should be available to the public soon. Some of the interviews have been published in edited form in Landigeist und Judenstempel: Erinnerungen einer Generation 1930-1945, ed. Christof Dejung, Thomas Gull, and Tanja Wirz (Zurich, 2002).

${ }^{74}$ Simone Chiquet, "Viel Selbstbewusstsein-wenig Erfolg: Der Schweizerische FHD-Verband 1944-1948," in Weiblich, männlich, Geschlechterverhältnisse in der Schweiz: Rechtsprechung, Diskurs, Praktiken, ed. Rudolf Jaun and Brigitte Studer (Zurich, 1995), 186.

${ }^{75}$ Interview with Madeleine M., March 21, 2001, Oral-History-Projekt Archimob. 
had a very horrible name for us - I almost dare not say it. FHD — they said this abbreviation stood for Feld-Huren-Dienst [Field whore service]. That was really bad." 76

\section{CONTINUITY AFTER 1945}

As the war came to an end in Europe in the spring of 1945, Switzerland gave thanks to the same figures, if not always in the same order: God, the Federal Council, and above all the general and his soldiers. "Thanks belong to our army," Basel business school students learned, "which, as tiny as it appeared among the mammoth forces, stood behind the barbed wire with fierce determination and ... hollowed out entire mountains on which foreign arrogance was to be shattered." "77 General Guisan, too, in his "Order of the Day" for May 8, 1945, emphasized the army's role: "Our army was and is our Schutz und Schirm [protector]. It has preserved us from misery and suffering, from war, occupation, destruction, bondage, and deportation." 78 Paradoxically, this gratitude was expressed even though the Swiss army was not involved in any combat during World War II (with the exception of some air battles with German planes in the summer of 1940). It is true that fear of a German invasion hung like Damocles' sword over the Swiss population continually after 1939, but for soldiers the war meant position building, maneuvers, combat training, and drills. It was precisely the fact that the Swiss army had not needed to fight that promoted the army's symbolic meaning. While in the warring countries the traditional gender order was shaken by World War II, ${ }^{79}$ in Switzerland this order not only remained stable but was even made more secure through the war. Annette Frei Berthoud holds the view that the position of Swiss men relative to women was never so strong as in the years after World War II. ${ }^{80}$

In the face of the uncertain international situation during the cold war, an overwhelming majority of the Swiss population was of the opinion that the country's independence was fundamentally based on maintaining a strong

${ }^{76}$ Interview with Jeannette C., May 19, 2000, Oral-History-Projekt Archimob.

${ }^{77}$ General Guisan, quoted in Mario König, "Die Verlegenheit vor dem Frieden: Vom schweizerischen Umgang mit dem Ende des Zweiten Weltkriegs," in "Mai 1945," special issue, Traverse: Zeitschrift für Geschichte, no. 2 (1995), S13.

${ }^{78}$ General Henri Guisan, “Order of the Day,” May 8, 1945, BAR, E 27/14112.

${ }^{79}$ For Germany after 1945, see, e.g., Svenja Goltermann, "Die Beherrschung der Männlichkeit: Zur Deutung psychischer Leiden bei den Heimkehrern des Zweiten Weltkriegs-1945-1956," Feministische Studien 18, no. 2 (2000): 7-19; Frank Biess, "Men of Reconstruction-the Reconstruction of Men: Returning POWs in East and West Germany, 1945-1955," in Hagemann and Schüler-Springorum, Home/Front, 335-58.

${ }^{80}$ Frei Berthoud, "Fakten, Mythen, Erinnerungen," 107. 
army. After 1945, Switzerland undertook a massive military buildup and became-relative to the number of soldiers per square kilometer, as well as relative to the number of fighter planes, tanks, and guns per capita- the most well-armed country in Western Europe. ${ }^{81}$ Justification for this buildup was found not least in the notion that the army had allegedly protected the country from German invasion in World War II. The high political status the army enjoyed in the postwar era was thus closely connected to Swiss cultural memory after 1945 , cultural memory in which military comradeship played a central role. As early as 1944, Major de Traz had expressed the hope that comradeship would emanate into civil society: "It is to be hoped that military comradeship will inform civilian life and clarify and develop the communal feeling. And that, for example, even the term 'unity,' understood broadly, will take on national significance." 82 General Guisan, too, continually stressed that the soldiers' common experience while on active service should constitute a basis for overcoming political antagonisms, thereby explicitly making military comradeship the standard for civil society. Thus he wrote on August 20, 1945 , in his last "Order of the Day," that the army had "collected experiences of mutual understanding and assistance whose benefit ought to be transferred to our entire communal life as a people." 83 This discourse on comradeship fit well with the positive historical image of World War II Switzerland that dominated in the postwar era. In this image, Switzerland appears as a national community that was fundamentally informed by military strength and its soldiers' comradely bonds. In 1965, for example, the military historian Hans Rudolf Kurz declared the army to be the symbolic center of "Switzerland at war": "The army-the people armed-was the pervasive force. . . From the army there continually streamed impulses and goads that invigorated and strengthened the entire nation." 84 Alternative memories that contradicted this long-standing and dominant historical image-Switzerland's economic cooperation with the Axis powers, the antisemitic aspects of its refugee policy, and the sympathies that segments of its social elites displayed for fascism and National Socialism-were for a long time discussed only in private or semiprivate spheres, never in public. The comradeship ideology papered over memories that might otherwise have disturbed the domestic peace. ${ }^{85}$

By contrast, progressive women's unions' hopes that women would receive

${ }^{81}$ Jakob Tanner, "Militär und Gesellschaft in der Schweiz nach 1945," in Militär und Gesellschaft im 19. und 20. Jahrhundert, ed. Ute Frevert (Stuttgart, 1997), 318-20, 329.

82 de Traz, "Sur la camaraderie," 394.

${ }^{83}$ General Henri Guisan, "Order of the Day," August 20, 1945, BAR, E 27/14112.

${ }^{84}$ Kurz, Dokumente des Aktivdienstes, 7.

${ }^{85}$ Christof Dejung, "Dissonant Memories: National Identity, Political Power, and the Commemoration of World War Two in Switzerland," Oral History 35, no. 2 (2007): 57-66. 
the right to vote on the national level as a reward for their service in the war were bitterly disappointed. This suggests that women were not automatically granted political rights as a reward for their wartime contributions, as has frequently been argued, but that social and political developments also played a role. It is true that at the end of the war numerous authorities offered their thanks to women for their work. Yet on the occasion of a speech marking the end of the activities of the civilian FHD in December 1945, Rudolf Briner, president of the canton of Zurich, claimed that women did not need "any official thanks [for their work], neither from the organs of the civilian Women's Auxiliary Service nor from the authorities," for the greatest thanks is "the consciousness of duty loyally fulfilled." Clearly, selfless service without demands for political equality was what marked the true Swiss woman in Briner's eyes. Briner closed his speech with a hymn to democracy, something that would have to remain the exclusive business of men: "With her being, her virtues, and her abilities, the woman must complete the man in the political arrangement of the community and the state. Only through the cooperation of both principles, the masculine and the feminine, will the creation of the just social state, the state of the future, succeed." 86

As early as a year later there was no more talk of men owing women a "debt of gratitude." The proclaimed national Schicksalsgemeinschaft (community of fate) constituted a primarily male concern. The contemporary image of women was predominantly shaped at this time by Right bourgeois and Catholic Conservative circles that promoted an apolitical role for women as mothers, wives, and housekeepers. ${ }^{87}$ The women's unions were somewhat responsible for the persistent survival of this image. Insofar as they completely integrated themselves, beginning in the 1930s, into the Swiss Volksgemeinschaft (people's community) and the military defense of the nation, they also took on the gender models that came with these positions. As a result, political demands for women's suffrage lacked an ideological basis. For men, accordingly, it seemed unnecessary to grant women full civil rights because it had been shown that even without those rights women had done what was expected of them. ${ }^{88}$

Things looked very different in the arena of compromise in class politics, however. The exalted status the army enjoyed in the prevailing historical narrative

${ }^{86}$ Excerpt from the address of Dr. Rudolf Briner on the occasion of the disbandment of the civilian WAS, December 11, 1945, quoted in Haemmerli-Schindler, Zürcherfrauen erleben den Zivilen Frauenhilfsdienst, 72-74.

${ }^{87}$ Matthias Kunz, Aufbruchstimmung- und Sonderfall-Rhetorik, Bundesarchiv Dossier 8 (Bern, 1999), 101-8.

${ }^{88}$ Regula Zürcher, "Das Unbehagen im Staat: Die schweizerische Frauenbewegung, die Landesausstellung 1939, und das Bundesstaatsjubiläum 1948," Schweizerische Zeitschrift für Geschichte 48 (1998): 470. 
eased the integration of moderate leftists into the postwar bourgeois-dominated political cartel. The wartime feeling of solidarity laid the groundwork in the immediate postwar period for sociopolitical and party-political reforms that had been completely unthinkable at the beginning of the 1930s. In 1947, for example, nearly 80 percent of voting males decided in favor of a bill for the creation of old-age and surviving-dependent insurance, which was created on the basis of the wartime experience with the wage-and-income-compensation law for mobilized soldiers. This insurance was - and remained - a symbol of the national compromise between the bourgeoisie and the workers' movement and thus represented an indirect product of the united national wartime society. Of course, women were meant to be included in this national community, but their interests played a clearly subordinate role relative to those of men.

Furthermore, from 1959 on, the bourgeois-conservative majority, in the context of the so-called magic formula, permanently granted the Social Democrats two of the seven seats in the national government. Although the magic formula was only an informal agreement, it was subsequently adhered to continually. ${ }^{89}$ Political emancipation for women, by contrast, would have to wait. The national Solidargemeinschaft (community of solidarity) based itself after 1945 on the community-forming experience men had had in their military service, which did not produce a basis for demanding political emancipation for women. Male solidarity across political divisions was possible because of this experience and was one reason why the demand for economic and political equality for women found no resonance for so long. In the first years after the war there were referendums on cantonal or communal women's suffrage in several cantons, but all failed to pass. ${ }^{90}$ And in 1959, more than 66 percent of male voters roundly rejected the introduction of women's rights on the national level..$^{91}$ During the national referendum campaign, the view that the right to vote was a correlate of having completed military service found frequent expression. ${ }^{92}$ Many voters therefore concluded that there was no basis for women's demands for politcal equality. Pointing out that thousands of Swiss women had taken part in the wartime defense of the country through their participation in the WAS, and also that Swiss men who did not perform military service were nonetheless allowed to

${ }^{89}$ Mario König, "Politik und Gesellschaft im 20. Jahrhundert: Krisen, Konflikte, Reformen," in Eine kleine Geschichte der Schweiz: Der Bundesstaat und seine Traditionen, ed. Manfred Hettling et al. (Frankfurt am Main, 1998), 58, 76.

${ }^{90}$ Referendums on women's suffrage were held in various cantons and communities: Basel-City, Basel-Country, Geneva, and Tessin in 1946; Zurich in 1947; Neuenburg and Solothurn in 1948; and Waadt in 1951. See Mesmer, Staatsbürgerinnen ohne Stimmrecht, 270-78.

${ }^{91}$ Rudolf Jaun, “'Weder Frauen-Hauswehr noch Frauen-Stimmrecht': Zum Zusammenhang von Geschlecht, Stimmrecht, und Wehrpflicht in der Schweiz," Itinera 20 (1998): 125-36.

92 Neue Zürcher Zeitung, February 25, 1957. 
vote, advocates of women's suffrage such as Rudolf Schwarz argued against the claim that "only those who have defended the country are to rule it"- but in vain. ${ }^{93}$ Because of the sociopolitical reforms during wartime and the postwar era, there was no political leveraging factor that could threaten the prevailing power structure. From the 1930s on, the workers' movement supported the democratic society and the military defense of the nation, and for decades after 1945 it maintained a historical narrative in which the army played the central role. For their part, bourgeois men were not forced to share power with women because there was no need to defuse social tensions - the reforms had already mitigated them. ${ }^{94}$

Not until the 1960s, with the rise of mass consumerism and the leisure society, did Switzerland's hero discourse and martial self-understanding run their course and criticism of the military sector become louder. ${ }^{95}$ With the easing of the cold war and the rise of an extraparliamentary leftist opposition, more and more participants began to examine critically the prevailing history of the Second World War. ${ }^{96}$ As a new generation of women's rights activists began to raise more and more vigorous critiques of the patriarchal societyagainst a fundamentally new background of social and gender politics ${ }^{97}$ - the women's movement created a new ideological basis for the demand for political, economic, and legal equality between men and women. Finally, in 1971, Swiss women-among the last in Europe ${ }^{98}$ - achieved full political rights after almost 66 percent of men voted in a referendum to give women the right to vote..$^{99}$

${ }^{93}$ Rudolf Schwarz, Zwei Dutzend Einwände gegen das Frauenstimmrecht und was ich darauf antworte, ed. Schweizerischer Verband für das Frauenstimmrecht (n.p., n.d.), 20-21.

${ }^{94}$ The Communists, of course, were a beloved bourgeois bogeyman, but they possessed almost no tangible political weight.

95 Tanner, "Militär und Gesellschaft in der Schweiz," 333-40.

${ }^{96}$ König, "Politik und Gesellschaft im 20. Jahrhundert," 74; Georg Kreis, "Vier Debatten und wenig Dissens," Schweizerische Zeitschrift für Geschichte 47 (1997): 451-76.

${ }^{97}$ Studer, “L'État c'est l'homme”"; Thébaud, "Der Erste Weltkrieg," 91.

${ }^{98}$ Women's suffrage came later only to Liechtenstein, in 1984.

${ }^{99}$ Voegeli, Zwischen Hausrat und Rathaus, 643-68, 683-86. 